This article was downloaded by: [McMaster University]

On: 20 December 2014, At: 17:24

Publisher: Taylor \& Francis

Informa Ltd Registered in England and Wales Registered Number: 1072954 Registered office: Mortimer House, 37-41 Mortimer Street, London W1T 3J H, UK

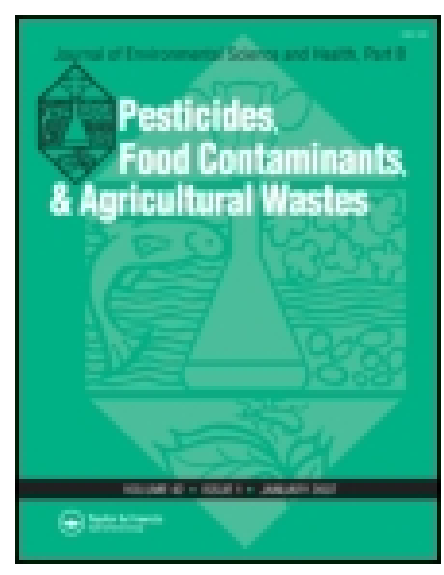

J ournal of Environmental Science and Health, Part B:
Pesticides, Food Contaminants, and Agricultural Wastes

Publication details, including instructions for authors and subscription information:

http:// www.tandfonline.com/loi/lesb20

Glucose, stem dry weight variation, principal component and cluster analysis for some agronomic traits among 16 regenerated Crotalaria juncea accessions for potential cellulosic ethanol

\author{
J. Bradley Morris ${ }^{a} \&$ George F. Antonious ${ }^{b}$ \\ ${ }^{a}$ U.S. Department of Agriculture, Agricultural Research Service, Plant Genetic Resources \\ Conservation Unit, Griffin, Georgia, USA \\ ${ }^{b}$ College of Agriculture, Food Science, and Sustainable Systems, Division of Environmental \\ Studies, Kentucky State University, Frankfort, Kentucky, USA \\ Published online: $28 \mathrm{~J}$ an 2013.
}

To cite this article: J. Bradley Morris \& George F. Antonious (2013) Glucose, stem dry weight variation, principal component and cluster analysis for some agronomic traits among 16 regenerated Crotalaria juncea accessions for potential cellulosic ethanol, J ournal of Environmental Science and Health, Part B: Pesticides, Food Contaminants, and Agricultural Wastes, 48:3, 214-218, DOI: $10.1080 / 03601234.2013 .730333$

To link to this article: http:// dx.doi.org/ 10.1080/03601234.2013.730333

PLEASE SCROLL DOWN FOR ARTICLE

Taylor \& Francis makes every effort to ensure the accuracy of all the information (the "Content") contained in the publications on our platform. However, Taylor \& Francis, our agents, and our licensors make no representations or warranties whatsoever as to the accuracy, completeness, or suitability for any purpose of the Content. Any opinions and views expressed in this publication are the opinions and views of the authors, and are not the views of or endorsed by Taylor \& Francis. The accuracy of the Content should not be relied upon and should be independently verified with primary sources of information. Taylor and Francis shall not be liable for any losses, actions, claims, proceedings, demands, costs, expenses, damages, and other liabilities whatsoever or howsoever caused arising directly or indirectly in connection with, in relation to or arising out of the use of the Content.

This article may be used for research, teaching, and private study purposes. Any substantial or systematic reproduction, redistribution, reselling, loan, sub-licensing, systematic supply, or distribution in any form to anyone is expressly forbidden. Terms \& Conditions of access and use can be found at http:// www.tandfonline.com/page/terms-and-conditions 


\title{
Glucose, stem dry weight variation, principal component and cluster analysis for some agronomic traits among 16 regenerated Crotalaria juncea accessions for potential cellulosic ethanol
}

\author{
J. BRADLEY MORRIS ${ }^{1}$ and GEORGE F. ANTONIOUS ${ }^{2}$ \\ ${ }^{1}$ U.S. Department of Agriculture, Agricultural Research Service, Plant Genetic Resources Conservation Unit, Griffin, Georgia, USA \\ ${ }^{2}$ College of Agriculture, Food Science, and Sustainable Systems, Division of Environmental Studies, Kentucky State University, \\ Frankfort, Kentucky, USA
}

\begin{abstract}
The objectives of this research were to identify candidate sunn hemp accessions having high concentrations of cellulose for use as parents in breeding for cellulose and to determine variability for glucose content and some important agronomic traits among sunn hemp accessions. Since sunn hemp is an under-utilized species, glucose content and agronomic trait variation is essential for the identification of superior sunn hemp accessions for use as potential ethanol for biofuel. Sixteen sunn hemp accessions including the following plant introductions (expressed as glucose concentration) and stem dry weights were studied. "Sixteen sunn hemp accessions including the following plant introductions (expressed as glucose concentration) and stem dry weights were studied." In addition, to verify variability, these traits plus morphological, phenological, and seed reproductive traits were analyzed using multivariate and cluster analysis. The accessions, PI 250487, PI 337080, and PI 219717 produced the highest glucose concentrations (859, 809, and $770 \mathrm{mg} \mathrm{g}^{-1}$ stem dry weight, respectively), however PI 468956 produced the highest stem dry weight (258 g). Branching significantly correlated with foliage $\left(\mathrm{r}^{2}=0.67^{* *}\right)$ and relative maturity $\left(\mathrm{r}^{2}=0.60^{*}\right)$, while maturity had a significantly negative correlation with seed number $\left(\mathrm{r}^{2}=-0.67^{* *}\right)$ and plant width $\left(\mathrm{r}^{2}=-0.53^{*}\right)$ as well. Seed number significantly correlated with plant width $\left(\mathrm{r}^{2}=0.57^{*}\right)$. Average linkage cluster analysis grouped the 16 sunn hemp accessions into well-defined phenotypes with four distinct seed-producing groups and one outlier. Based on multivariate and cluster analysis, sufficient variation among these16 sunn hemp accessions exists to support the development of cellulosic ethanol producing cultivars with improved architecture, early maturity, seed yield, glucose concentrations, and stem dry weights.
\end{abstract}

Keywords: Crotalaria juncea, principal component, cluster analysis, agronomic, cellulose, ethanol.

\section{Introduction}

Sixteen sunn hemp accessions have shown variability for earliness, phenotype, seed reproduction, and successful cultivation in Georgia, ${ }^{[1]}$ Florida, and Puerto Rico. ${ }^{[2]}$ Sunn hemp also performed well in a mid-Atlantic region of the U.S. ${ }^{[3]}$ and it has been shown to be very useful as a rotation crop with cotton in low organic matter soils in the southeastern U.S. ${ }^{[4]}$ Weedy grass, broadleaves, and sedges have been reduced in sunn hemp plots in Georgia,${ }^{[5]}$ Florida, ${ }^{[5]}$ and Alabama. ${ }^{[6]}$ The results from the Georgia and Florida studies are in preparation, however prevalent weedy species

Address correspondence to J. Bradley Morris, Plant Genetic Resources Conservation Unit, United States Department of Agriculture, Agricultural Research Service; E-mail: Brad.Morris@ars. usda.gov

Received June 26, 2012. in the Alabama study included large crabgrass [Digitaria sanguinalis (L.) Scop], yellow nutsedge (Cyperus esculentus L.), red root pigweed (Amaranthus retroflexus L.), sicklepod [Senna obtusifolia (L.) Irwin and Barnaby], and stinkgrass [Eragrostis cilianensis (All.) E. Mosher]. They found a reduction in overall weed biomass. Sunn hemp leaves are suggested to contain the phytotoxic non-protein amino acid, hydroxynorleucine which may impact weed growth through allelopathy. ${ }^{[5]}$

Most of the current ethanol for use as biofuel in North America originates from corn grain as the main feedstock. ${ }^{[7]}$ Recently, sunn hemp was found to exceed cowpea (Vigna unguiculata) for biomass yield as well as containing higher energy content than switchgrass, bermudagrass, reed canarygrass, and alfalfa. ${ }^{[8]}$ Several sunn hemp accessions exhibiting high biomass traits include PI 234771, PI 248491, PI 295851, PI 337080, PI 468956, PI 561720, and PI 652939. ${ }^{[9]}$ Accordingly, each of these sunn hemp accessions 
has potential utilization in a hybridization program to enhance biomass for cellulosic ethanol production.

The USDA, ARS, Plant Genetic Resources Conservation Unit's (PGRCU) sunn hemp germplasm collection contains 22 accessions from several countries of origin. ${ }^{[10]}$ Sixteen accessions of the most seed reproductive were selected to represent various countries of origin. Limited information is currently available on glucose, dry stem weight, morphology, phenology, and reproductive traits in this USDA, ARS, PGRCU sunn hemp collection. Variability for glucose content, dry stem weight, morphology, phenology, and reproduction among sunn hemp accessions is a factor when selecting genotypes for breeding programs. The objectives of this research were 1) to determine cellulosic content (expressed as glucose units) and stem dry weights of the most seed productive accessions, 2) analyze morphology, phenology, and seed reproduction among these same accessions using multivariate/cluster analysis, and 3) to select candidate accessions of sunn hemp for use as a feedstock source of cellulosic ethanol in breeding programs.

\section{Materials and methods}

Approximately 50 seeds from each sunn hemp accession $(\mathrm{n}=16)$ were directly seeded to field plots consisting of a clayey, kaolinitic, thermic typic kanhapludults soil series at Griffin, GA during the first week of June 2008. About 25-50 plants representing each accession were regenerated in one $6 \mathrm{~m}$ row plot with at least 5 different buffer species planted between each sunn hemp accession. Plots were irrigated using sprinklers as necessary. Characterization data including branching, foliage, plant height, plant width, relative maturity, and seed number were recorded from plants in each plot at 50\% flowering. Branching and foliage were based on a scale of $1-9$ where, $1=>90 \%, 2=80-89 \%$, $3=70-79 \%, 4=60-69 \%$, and $5=50-59 \%, 6=40-49 \%$, $7=30-39 \%, 8=20-29 \%$, and $9=10-19 \%$ of each plant producing branches and/or foliage based on visual observations. Relative maturity dates were based on a scale of 5 to 9 where $5=$ mid-season and $9=$ very late. Total seed numbers per accession were counted at the end of the regeneration cycle.

When the sunn hemp plants had reached full maturity, 10 main stems from each accession were cut, dried, and weighed. The samples were then sent to the Division of Environmental Studies Laboratory at the College of Agriculture, Kentucky State University, Frankfort, KY, for cellulose analysis. Crude cell wall preparation was conducted based on the method used by Reiter et al. (1993). ${ }^{[11]}$ Cellulose was determined using the method described by Updegraff (1960). ${ }^{[12]}$

Both glucose and stem dry weights from sunn hemp accessions were analyzed using an analysis of variance (ANOVA) and means were separated using Duncan's multi- ple range test. ${ }^{[13]}$ Principal component analysis and PC SAS procedure CLUSTER analysis were then used from multivariate analysis of the data. ${ }^{[13]}$ Eigenvalues, the percentage of variances explained by each principal component, and clustering of accessions were also determined. ${ }^{[13]}$ Standard errors (SE) and coefficients of variation (CV) were also determined to confirm variability using principal component analysis. ${ }^{[13]}$

\section{Results and discussion}

Significant variations for glucose and stem dry weights were observed in the 16 sunn hemp accessions tested (Table 1). Glucose concentrations ranged from 275 to $859 \mathrm{mg} \mathrm{g}^{-1}$ among accessions. The accessions, PI 250487 (India), PI 337080 (Brazil), and PI 219717 (Myanmar) produced the highest concentrations of glucose $(859,809$, and $770 \mathrm{mg}$ $\mathrm{g}^{-1}$, respectively). The U.S. developed cultivar, Tropic Sunn (PI 468956) produced one of the lowest concentrations of glucose $\left(368.2 \mathrm{mg} \mathrm{g}^{-1}\right)$ among all accessions tested. Overall, stem dry weights ranged from 52 to $258 \mathrm{~g}$ among accessions and Tropic Sunn produced the heaviest dry stems ( $258 \mathrm{~g}$ per accession) when compared to the other sunn hemp accessions. However, PI 250485 (India) produced the lowest stem dry weight $(52 \mathrm{~g})$. The coefficient of variation for glucose and stem dry weights were $40 \%$ and $60 \%$, respectively indicating a fairly high degree of variation between individuals

Table 1. Glucose concentration and stem dry weight variation among 16 sunn hemp accessions grown at USDA, ARS (Griffin, GA).

\begin{tabular}{llcc}
\hline \multicolumn{4}{c}{ Accession } \\
\hline PI) & \multicolumn{1}{c}{ Origin } & Glucose, $\mathrm{mg}^{-1}$ & Stem dry weight, $g$ \\
\hline 250487 & India & $859.1 \mathrm{a}$ & $73.5 \mathrm{de}$ \\
337080 & Brazil & $808.5 \mathrm{ab}$ & $176.7 \mathrm{abcd}$ \\
219717 & Myanmar & $770.4 \mathrm{ab}$ & $208.1 \mathrm{abc}$ \\
175106 & India & $634.4 \mathrm{abc}$ & Not recorded \\
250485 & India & $609.6 \mathrm{bcd}$ & $51.7 \mathrm{e}$ \\
207657 & Sri Lanka & $471.4 \mathrm{cde}$ & $120.9 \mathrm{bcde}$ \\
561720 & Brazil & $451.4 \mathrm{cde}$ & $163.9 \mathrm{abcde}$ \\
274948 & Guadeloupe & $393.4 \mathrm{de}$ & $73.6 \mathrm{de}$ \\
468956 & United States & $368.2 \mathrm{e}$ & $257.6 \mathrm{a}$ \\
322377 & Brazil & $367.5 \mathrm{e}$ & $215.3 \mathrm{abc}$ \\
250486 & India & $356.3 \mathrm{e}$ & $115.2 \mathrm{bcde}$ \\
346297 & India & $345.0 \mathrm{e}$ & Not recorded \\
314239 & Former Soviet & $333.0 \mathrm{e}$ & $182.8 \mathrm{abcd}$ \\
& Union & $319.2 \mathrm{e}$ & $230.5 \mathrm{ab}$ \\
234771 & Nigeria & $286.2 \mathrm{e}$ & $181.9 \mathrm{abcd}$ \\
248491 & Brazil & $274.5 \mathrm{e}$ & $91.8 \mathrm{cde}$ \\
295851 & Brazil & 48.17 & 20.03 \\
SE & & 40 & 60 \\
CV (\%) & & &
\end{tabular}

$\dagger$ Values within a column having different letter (s) are significantly different $(P<0.05)$, using Duncan's multiple range test (SAS Institute). ${ }^{[14]}$ 
Table 2. Morphological, phenological, and reproductive trait variation among 16 sunn hemp accessions grown at USDA, ARS, Griffin, GA.

\begin{tabular}{|c|c|c|c|c|c|c|}
\hline \multirow[b]{2}{*}{$\begin{array}{l}\text { Accession } \\
(P I)\end{array}$} & \multirow[b]{2}{*}{$\begin{array}{l}\text { Branching } \\
(\mathrm{cm})\end{array}$} & \multirow[b]{2}{*}{$\begin{array}{c}\text { Foliage } \\
\text { (cm) }\end{array}$} & \multicolumn{2}{|c|}{ Plant } & \multirow[b]{2}{*}{$\begin{array}{c}\text { Maturity } \dagger \\
\text { relative }\end{array}$} & \multirow[b]{2}{*}{ Seed number } \\
\hline & & & $\begin{array}{l}\text { Height } \\
(\mathrm{cm})\end{array}$ & $\begin{array}{c}\text { Width } \\
(\mathrm{cm})\end{array}$ & & \\
\hline 250487 & 1 & 3 & 192 & 140 & 5 & 4412 \\
\hline 337080 & 5 & 4 & 257 & 120 & 9 & 3010 \\
\hline 219717 & 9 & 6 & 210 & 150 & 9 & 4871 \\
\hline 175106 & 5 & 5 & 160 & 100 & 9 & 268 \\
\hline 250485 & 5 & 5 & 140 & 100 & 9 & 5009 \\
\hline 207657 & 1 & 3 & 195 & 150 & 5 & 4983 \\
\hline 561720 & 1 & 1 & 200 & 120 & 9 & 0 \\
\hline 274948 & 5 & 5 & 200 & 130 & 9 & 0 \\
\hline 468956 & 9 & 9 & 210 & 100 & 9 & 0 \\
\hline 322377 & 3 & 5 & 205 & 137 & 5 & 2883 \\
\hline 250486 & 5 & 5 & 170 & 120 & 5 & 4132 \\
\hline 346297 & 5 & 5 & 200 & 140 & 9 & 0 \\
\hline 314239 & 1 & 5 & 196 & 142 & 5 & 7379 \\
\hline 234771 & 5 & 2 & 230 & 80 & 9 & 0 \\
\hline 248491 & 5 & 5 & 180 & 60 & 9 & 0 \\
\hline 295851 & 5 & 3 & 290 & 90 & 9 & 0 \\
\hline SE & 0.62 & 0.45 & 8.89 & 6.66 & 0.47 & 634 \\
\hline CV $(\%)$ & 57 & 41 & 18 & 23 & 25 & 110 \\
\hline
\end{tabular}

$\dagger$ Relative maturity was estimated based on a scale of 5 to 9 , where $5=$ midseason and $9=$ very late.

$\ddagger$ Relative seed production was also based on a scale of 1 to 9 , where $1=$ very high seed production and $9=$ very low seed production.

within the same sunn hemp accession. Even though significant variation for both glucose concentrations and stem dry weights were detected, future studies will require similar evaluations over 2 years.

The morphological, phenological, and seed reproductive analysis is shown in Table 2. Percentages of each plant producing branches and foliage ranged from 10 to greater than $90 \%$. Plant height within rows ranged from 140 to $290 \mathrm{~cm}$. The accessions producing the tallest plants were PI 295851 $(290 \mathrm{~cm})$, PI $337080(257 \mathrm{~cm})$, and PI $234771(230 \mathrm{~cm})$. Plant widths ranged from 60 to $150 \mathrm{~cm}$ and the widest plant

Table 3. Phenotypic, glucose, and stem dry weight traits in sunn hemp grown at USDA, ARS, Griffin, GA.

\begin{tabular}{|c|c|c|c|c|c|}
\hline Variable & Maximum & Minimum & Range & Mean & $S D$ \\
\hline Glucose $\left(\mathrm{mg} \mathrm{g}^{-1}\right)$ & 859 & 275 & 584 & 482 & 193 \\
\hline Stem dry weight (g) & 258 & 52 & 206 & 134 & 80 \\
\hline Branching $^{1}$ & 9 & 1 & 8 & 4 & 3 \\
\hline Foliage $^{2}$ & 9 & 1 & 8 & 4 & 2 \\
\hline Plant height $(\mathrm{cm})$ & 290 & 140 & 150 & 202 & 36 \\
\hline Relative maturity $^{3}$ & 9 & 5 & 4 & 8 & 2 \\
\hline Seed number & 7379 & 0 & 7379 & 2309 & 2540 \\
\hline Plant width (cm) & 150 & 60 & 90 & 117 & 27 \\
\hline
\end{tabular}

${ }^{1,2}$ Branching and foliage were based on a scale of $1-9$ where, $1=$ $>90 \%, 2=80-89 \%, 3=70-79 \%, 4=60-69 \%, 5=50-59 \%, 6=40-49 \%$, $7=30-39 \%, 8=20-29 \%$, and $9=10-19 \%$ of each plant producing branches and/or foliage based on visual observations.

${ }^{3}$ Relative maturity dates were based on a scale of 5 to 9 where $5=$ midseason and $9=$ very late.
Table 4. Eigenvalues and the proportion of total variability among sunn hemp accessions as explained by the principal components.

\begin{tabular}{lccc}
\hline Principal component & Eigenvalue & $\%$ Variability & $\%$ Cumulative \\
\hline 1 & 2.7443 & 34.30 & 34.30 \\
2 & 1.6304 & 20.38 & 54.69 \\
3 & 1.3457 & 16.82 & 71.51 \\
4 & 1.0870 & 13.59 & 85.10 \\
5 & 0.5927 & 7.41 & 92.51 \\
\hline
\end{tabular}

sizes were observed in PI 219717 and PI $207657(150 \mathrm{~cm})$. The coefficient of variation for plant height and plant width were $18 \%$ and $23 \%$, respectively, indicating a low degree of variation between individuals within the same sunn hemp accession. Relative plant maturity for sunn hemp accessions ranged from 5 to 9 . The accessions, PI 250487, PI 207657, PI 322377, PI 250486, and PI 314239 matured at mid-season. The coefficient of variation for relative maturity was $25 \%$, indicating a fairly low degree of variation between individuals within the same accession. The leading seed producing accessions were PI 250485 and PI 314239 with a high coefficient of variation $(110 \%)$ which indicates a high degree of variation between individuals within the same accession. Further evidence for variability in glucose, stem dry weights, plant heights, and plant widths were observed from wide ranges for these characteristics (Table 3).

Principal component analysis accounted for $34 \%$ of the total variation at the first principal component (Table 4). The amount of variation accounted for, cumulatively, by adding principal components 2 through 5 was $55,72,85$, and $93 \%$, respectively. The first principal component was most correlated with relative maturity and seed number (Table 5). The second principal component accounted for

Table 5. Eigenvectors and principal components for glucose, stem dry weight, morphological, phenological, and reproductive traits in sunn hemp accessions grown at USDA, ARS, Griffin, GA.

\begin{tabular}{|c|c|c|c|c|c|}
\hline & \multicolumn{5}{|c|}{ Principal components } \\
\hline & 1 & 2 & 3 & 4 & 5 \\
\hline Glucose & -0.22 & 0.29 & -0.33 & 0.63 & -0.40 \\
\hline Stem dry weight (g) & 0.12 & 0.06 & 0.75 & 0.07 & -0.46 \\
\hline Branching $^{1}$ & 0.42 & 0.49 & 0.04 & 0.15 & 0.07 \\
\hline Foliage $^{2}$ & 0.16 & 0.67 & 0.14 & -0.22 & 0.28 \\
\hline Plant height $(\mathrm{cm})$ & 0.19 & -0.31 & 0.39 & 0.59 & 0.37 \\
\hline Relative maturity ${ }^{3}$ & 0.49 & 0.02 & -0.30 & 0.27 & -0.11 \\
\hline Seed number & -0.48 & 0.27 & 0.19 & 0.03 & -0.25 \\
\hline Plant width $(\mathrm{cm})$ & -0.45 & 0.18 & 0.07 & 0.29 & 0.55 \\
\hline
\end{tabular}

${ }^{1,2}$ Branching and foliage were based on a scale of 1-5 where, $1=>90 \%$, $2=80-89 \%, 3=70-79 \%, 4=60-69 \%, 5=50-59 \%, 6=40-49 \%$, $7=30-39 \%, 8=20-29 \%$, and $9=10-19 \%$ of each plant producing branches and/or foliage based on visual observations.

${ }^{3}$ Relative maturity dates were based on a scale of 5 to 9 where $5=$ midseason and $9=$ very late. 


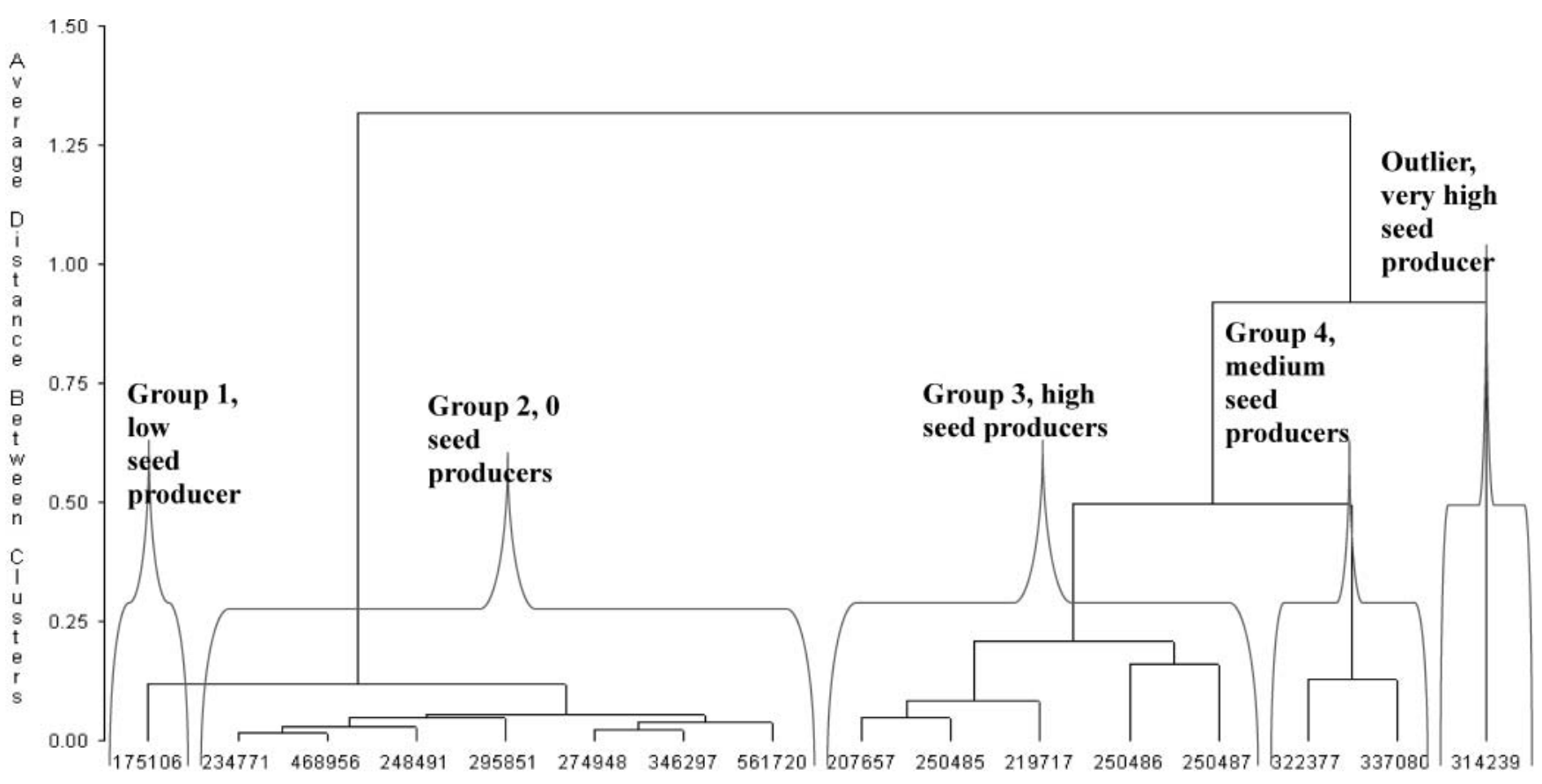

Acc

Fig. 1. Dendrogram of distance between clusters based on glucose concentration, stem dry weight, morphological, phenological, and reproductive differences. Accession numbers are given (Acc). Values on the baseline indicate average phenotypic distances between accessions. Four distinct clusters for seed production can be distinguished.

$20 \%$ of the variation and was mostly due to foliage production. The third principal component explained $17 \%$ of the variation and is composed primarily of stem dry weight. The fourth principal component explained $14 \%$ of the variation and consisted of glucose and plant height while the fifth principal component accounted for $7 \%$ of the variation consisting of plant width. Therefore, potential exists to develop cultivars with improved sunn hemp architecture, early maturity, seed yield, glucose and stem dry weights for use as a new biomass crop utilized for ethanol production. Branching was significantly correlated with foliage $\left(\mathrm{r}^{2}=0.67^{* *}\right)$ and relative maturity $\left(\mathrm{r}^{2}=0.60^{*}\right)$. Relative maturity had significantly negative correlations with seed number $\left(\mathrm{r}^{2}=-0.67^{* *}\right)$ and plant width $\left(\mathrm{r}^{2}=-0.53^{*}\right)$, respectively. Seed number was significantly correlated with plant width $\left(\mathrm{r}^{2}=0.57^{*}\right)$.

Average linkage cluster analysis grouped the original 16 sunn hemp accessions into well defined phenotypes with four distinct seed producing groups and one outlier (Fig. 1). Group 1 represents 1 low seed producing accession while group 2 consists of 7 accessions producing no seeds. Group 3 consists of 5 high seed producing accessions and group 4 represents 2 medium seed producing accessions. The outlier consisted of one accession producing very high seed numbers. Using distance values indicated in Figure 1, the groupings at any similarity level can be identified. For example, PI 322377 and PI 337080 originate from Brazil with a phenotypic distance index of 0.1286 , which indicates their close morphological similarities. These 16 sunn hemp accessions evaluated during the regeneration cycle consists of enough genetic variation for cultivar development based on coefficients of variation, principal component, and cluster analysis.

\section{Acknowledgments}

We thank Ken Manley for his assistance in planting, harvesting, characterizing, and preparing sunn hemp accessions for shipping to Kentucky State University.

\section{References}

[1] Morris, J. B.; Chase, C. A.; Cho, A. H.; Koenig, R L.; MoralesPayan, J. P. Earliness, morphological, and reproductive variation among 16 sunn hemp (Crotalaria juncea L.) accessions in Griffin, GA. Abstr. Assoc. Adv. Ind. Crops: Ft. Collins, CO, 2010 22, 46.

[2] Cho, A.H.; Chase, C.A.; Koenig, R.L.; Treadwell, D.D. Evaluation of phenotypic characteristics of sixteen accessions of sunn hemp in Florida. HortSci. Suppl. 2010, 45, 8.

[3] Bhardwaj, H.L.; Webber III, C.L.; Sakamoto, G.S. Cultivation of kenaf and sunn hemp in the mid-Atlantic United States. Ind. Crops Prod. 2005, 22, 151-155.

[4] Bauer, P.J.; Park, D.M.; Campbell, B.T. Cotton production in rotation with summer legumes. J. Cotton Sci. 2009, 13, 183-188.

[5] Chase, C.; Folta, K.; Hall, H. G.; Hodges, A.; Koenig, R.; Mesh, M.; Morales-Payan, J.; Morris, J.; Swisher, M.; Treadwell, D. 
Selecting a sunn hemp cover crop genotype for weed suppression and seed production, Project Report; Sustainable Agriculture Research \& Education (Southern SARE): University of Georgia, Griffin, GA, 2011. Available at http://mysare.sare.org/MySare/ ProjectReport.aspx?do $=$ viewRept $\& p n=L S 08-205 \& \mathrm{t}=1 \& \mathrm{y}=2011$ (retrieved April 11, 2012).

[6] Mosjidis, J.A.; Wehtje, G. Weed control in sunn hemp and its ability to suppress weed growth. Crop Protect. 2011, 30, 70-73.

[7] Mabee, W.E.; McFarlane, P.N.; Saddler, J.N. Biomass availability for lignocellulosic ethanol production. Biomass Bioen. 2011, 35, 4519-4529.

[8] Cantrell, K. B.; Bauer, P.J.; Kyoung, S. R. Utilization of summer legumes as bioenergy feedstocks. Biomass Bioen. 2010, 34, 1961-1967.
[9] Cho, A.H. Investigation of sunn hemp as a cover crop and a seed crop in Florida. 2010, MS thesis, University of Florida, Gainesville, FL. http://etd.fcla.edu/UF/UFE0042214/cho_a.pdf (retrieved April 11, 2012).

[10] National Plant Germplasm System. Germplasm Resources Information Network (GRIN). Database Management Unit (DBMU), National Plant Germplasm System; U.S. Department of Agriculture, Beltsville, MD, 2012.

[11] Reiter, W.D.; Chapple, C.C.S.; Somerville, C.R. Altered growth and cell walls in a fucose deficient mutant of Arabidopsis. Science 1993, $261,1032-1035$

[12] Updegraff, D.M. Semi-micro determination of cellulose in biological materials. Anal. Biochem. 1960, 32, 420-424.

[13] SAS Institute. SAS/STAT Guide, SAS Inc: Cary, NC, USA. 2008. 